medRxiv preprint doi: https://doi.org/10.1101/2021.04.27.21256140; this version posted April 27, 2021. The copyright holder for this preprint

(which was not certified by peer review) is the author/funder, who has granted medRxiv a license to display the preprint in perpetuity.

It is made available under a CC-BY-ND 4.0 International license .

\title{
Predicting daily COVID-19 case rates from SARS-CoV-2 RNA concentrations across a diversity of wastewater catchments
}

Alessandro Zulli ${ }^{1}$, Annabelle Pan ${ }^{1}$, Stephen M. Bart ${ }^{2,3}$, Forrest W. Crawford ${ }^{4,5,6,7}$, Edward H. Kaplan ${ }^{1,7,8}$, Matthew Cartter ${ }^{3,8}$, Albert I. Ko ${ }^{9}$, Duncan Cozens ${ }^{10}$, Marcela Sanchez ${ }^{1}$, Doug E. Brackney ${ }^{8,10}$, and Jordan Peccia ${ }^{1, *}$

${ }^{1}$ Department of Chemical and Environmental Engineering, School of Engineering and Applied Science, Yale University, New Haven, CT, USA

${ }^{2}$ Epidemic Intelligence Service, Centers for Disease Control and Prevention

${ }^{3}$ Connecticut Department of Public Health, Hartford, CT, USA

${ }^{4}$ Department of Biostatistics, Yale School of Public Health, Yale University, New Haven, CT, USA

${ }^{5}$ Department of Statistics and Data Science, Yale University, New Haven, CT, USA

${ }^{6}$ Department of Ecology and Evolutionary Biology, Yale University, New Haven, CT, USA

${ }^{7}$ Yale School of Management, Yale University, New Haven, CT, USA

${ }^{8}$ Yale School of Public Health, Yale University, New Haven, CT, USA

${ }^{9}$ Department of Epidemiology of Microbial Disease, Yale School of Public Health, Yale University, New Haven, CT, USA

${ }^{10}$ Connecticut Agricultural Experimental Station, State of Connecticut, New Haven, CT, USA

"Corresponding authors: Jordan Peccia, Tel: +1 (203) 432-4385; email: Jordan.Peccia@,Yale.edu

NOTE: This preprint reports new research that has not been certified by peer review and should not be used to guide clinical practice. 
medRxiv preprint doi: https://doi.org/10.1101/2021.04.27.21256140; this version posted April 27, 2021. The copyright holder for this preprint (which was not certified by peer review) is the author/funder, who has granted medRxiv a license to display the preprint in perpetuity.

It is made available under a CC-BY-ND 4.0 International license .

\section{Abstract}

47 We assessed the relationship between municipality COVID-19 case rates and SARS-CoV-2

48 concentrations in the primary sludge of corresponding wastewater treatment facilities. Over

491,000 daily primary sludge samples were collected from six wastewater treatment facilities with

50 catchments serving 18 cities and towns in the State of Connecticut, USA. Samples were analyzed

51 for SARS-CoV-2 RNA concentrations during a six-month time period that overlapped with fall

522020 and winter 2021 COVID-19 outbreaks in each municipality. We fit a single regression

53 model to estimate reported case rates in the six municipalities from SARS-CoV-2 RNA

54 concentrations collected daily from corresponding wastewater treatment facilities. Results

55 demonstrate the ability of SARS-CoV-2 RNA concentrations in primary sludge to estimate

56 COVID-19 reported case rates across treatment facilities and wastewater catchments, with

57 coverage probabilities ranging from 0.94 to 0.96 . Leave-one-out cross validation suggests that

58 the model can be broadly applied to wastewater catchments that range in more than one order of

59 magnitude in population served. Estimation of case rates from wastewater data can be useful in

60 locations with limited testing availability or testing disparities, or delays in individual COVID-19

61 testing programs.

62

\section{Keywords}

64 SARS-CoV-2, wastewater-based epidemiology, primary sludge, regression analysis, case rate 65 estimation, quantitative PCR

66

67

68 
medRxiv preprint doi: https://doi.org/10.1101/2021.04.27.21256140; this version posted April 27, 2021. The copyright holder for this preprint (which was not certified by peer review) is the author/funder, who has granted medRxiv a license to display the preprint in perpetuity.

It is made available under a CC-BY-ND 4.0 International license .

\section{Introduction}

70 Wastewater surveillance has the potential to identify and track outbreaks of human pathogens

71 that demonstrate gut tropism, including severe acute respiratory syndrome coronavirus 2 (SARS-

72 CoV-2), the causative agent of COVID-19. ${ }^{1}$ Recent studies demonstrate that SARS-CoV-2 RNA

73 concentrations in domestic wastewater reflect the rise and fall of COVID-19 cases based on daily

74 positive tests in a community, ${ }^{2-4}$ and important epidemiological parameters such as the effective

75 reproduction number can be estimated using wastewater SARS-CoV-2 concentrations, in

76 addition to other epidemic indicators. ${ }^{5}$ If SARS-CoV-2 wastewater results are rapidly reported,

77 they could provide a leading indicator of community infection rates over COVID-19 case rates

78 and hospital admissions data. ${ }^{5-7}$

79 Estimates of infection based on COVID-19 case rates from testing of human specimens have

80 been the standard for applying community interventions aimed at decreasing morbidity and

81 mortality. Alternative approaches to COVID-19 testing are necessary to estimate the number of

82 infections in locations with disparities in testing practices ${ }^{8}$, limited testing resources, ${ }^{9}$ or during

83 outbreaks when testing capacity cannot meet demand. SARS-CoV-2 RNA concentration

84 measurements in wastewater may resolve these issues, but quantitative relationships between

85 SARS-CoV-2 concentration in wastewater and infection (or proxies of infection such as cases)

86 are not well-resolved.

87 The following manuscript reports 192 days of monitoring daily primary sludge for SARS-

88 CoV-2 concentrations across six different U.S. wastewater treatment facilities ranging in over

89 one order of magnitude in flow rate, serving 18 municipalities and approximately 1 million

90 residents in the State of Connecticut, USA. Regression models were evaluated to estimate 
medRxiv preprint doi: https://doi.org/10.1101/2021.04.27.21256140; this version posted April 27, 2021. The copyright holder for this preprint (which was not certified by peer review) is the author/funder, who has granted medRxiv a license to display the preprint in perpetuity.

It is made available under a CC-BY-ND 4.0 International license .

91 community COVID-19 reported case rates from a time-course of primary sludge SARS-CoV-2

92 RNA concentrations.

94 Materials and Methods

95 Wastewater sampling. Primary sewage sludge samples of 40 to $45 \mathrm{ml}$ in volume were

96 collected daily from six wastewater treatment plants (WWTP) in the State of Connecticut, USA.

97 Table 1 lists the cities and towns served, and details the specific plant processes from which

98 primary sludge was produced and samples were withdrawn. Grab samples from Stamford,

99 Bridgeport, New Haven and New London were collected daily from August 3, 2020 to February

100

10, 2021. Samples from Hartford were collected daily from August 10, 2020 to February 10,

101 2021. Samples from Norwich were collected daily from August 17, 2020 to February 10, 2021.

102 All samples were collected between 8 am and $9 \mathrm{am}$, stored at $-20^{\circ} \mathrm{C}$ before being transported to

103 Yale University laboratories on ice, and analyzed immediately upon arrival.

104

SARS-CoV-2 RNA primary sludge concentrations. To quantify SARS-CoV-2 RNA

105 concentrations, the 40 to $45 \mathrm{ml}$ sample was mixed on a vortexer for 1 minute and $0.5 \mathrm{ml}$ of

106 primary sludge was added to a commercial extraction kit optimized for the isolation of total

107 RNA from raw wastewater (Zymo, Quick-RNA Fecal/Soil Microbe Microprep, wastewater

108 protocol). Modifications to the extraction protocol included the addition of $0.1 \mathrm{ml}$ of

109 phenol/chloroform/isoamyl alcohol (25:24:1) in the initial bead beating step and eluting isolated

110 RNA into $50 \mu \mathrm{l}$ of ribonuclease-free water. Before September 20, 2020 and prior to the rapid rise

111 in case rates in early October, primary sludge RNA extraction was accomplished using the

112 RNeasy PowerSoil Total RNA kit (Qiagen) as previously described. ${ }^{6}$ For all RNA extracts, total

113 RNA was measured by spectrophotometry and normalized to $200 \mathrm{ng} \mu \mathrm{L}^{-1}$ (NanoDrop, Thermo 
medRxiv preprint doi: https://doi.org/10.1101/2021.04.27.21256140; this version posted April 27, 2021. The copyright holder for this preprint (which was not certified by peer review) is the author/funder, who has granted medRxiv a license to display the preprint in perpetuity.

It is made available under a CC-BY-ND 4.0 International license .

114 Fisher Scientific) prior to quantitative PCR to account for daily variations in sludge solids

115 content.

SARS-CoV-2 RNA concentration was estimated using one-step qRT-PCR with SARS-CoV-2

$117 \mathrm{~N} 1$ and N2 primer sets. ${ }^{10,11}$ CrAssphage, a ubiquitous bacteriophage that is highly concentrated

118 in the human gut, ${ }^{12-14}$ was quantified as a PCR control. All primer sets were run in separate

119 reactions. Analysis was conducted using a one-step RT-qPCR kit (BioRad iTaq ${ }^{\mathrm{TM}}$ Universal

120 Probes One-Step Kit). Triplicate $20 \mu \mathrm{L}$ reactions using a $5 \mathrm{x}$ diluted template were run at $55^{\circ} \mathrm{C}$

121 for $10 \mathrm{~min}$ and $95^{\circ} \mathrm{C}$ for $1 \mathrm{~min}$, followed by 40 cycles consisting of $95^{\circ} \mathrm{C}$ for 10 seconds and $55^{\circ}$

$122 \mathrm{C}$ for 30 seconds $^{6}$ and $\mathrm{Ct}$ values for triplicates were average. N1 and N2 primer set standards

123 were constructed using ten-fold dilutions $\left(5 \times 10^{1}\right.$ to $5 \times 10^{8}$ copies per reaction $)$ of the $\mathrm{N}$ gene

124 transcripts for the SARS-CoV-2 Wuhan-Hu-1 strain. Concentrations in primary sludge samples

125 were calculated using these standard curves and are presented as SARS-CoV-2 RNA copies per

126 ng of total extracted RNA. Positive RNA and negative (no template) controls were included in

127 all qRT-PCR runs. Less than $1.5 \%$ of samples were not available from the treatment facilities. In

128 these cases, SARS-CoV-2 concentrations used in regression models were estimated by

129 interpolating between the prior and subsequent measured SARS-CoV-2 concentration.

130 COVID-19 test data for the cities served by the treatment facilities. The number of

131 confirmed and probable COVID-19 cases per the Council of State and Territorial

132 Epidemiologists case definition ${ }^{15}$ was provided by the Connecticut Department of Public Health

133 (CT DPH) and used in this analysis. The date for each case was assigned, in order of preference,

134 as test specimen collection date (if available), symptom onset date (if available), or date of report

135 to the CT DPH. Greater than $90 \%$ of reported case values were by date of clinical specimen

136 collection. Average test positivity rates over the study period were the following: Stamford 
medRxiv preprint doi: https://doi.org/10.1101/2021.04.27.21256140; this version posted April 27, 2021. The copyright holder for this preprint (which was not certified by peer review) is the author/funder, who has granted medRxiv a license to display the preprint in perpetuity.

It is made available under a CC-BY-ND 4.0 International license .

137 (6.2\%), Bridgeport (6.1\%), New Haven (3.7\%), Hartford (6.0\%), New London (4.6\%), Norwich $138(6.5 \%)$.

139 Cases were compiled from CT DPH data from the individual towns served by each

140 wastewater treatment plant (Table 1) and adjusted per 100,000 population based on town census

141 size. Under the assumption that each member of a population contributes an equivalent

142 volumetric flow of raw wastewater and primary sludge across the cities and towns considered,

143 the SARS-CoV-2 primary sludge concentrations reported here represent a per capita basis.

144 Model development. Multiple regression analysis was used to fit COVID-19 reported cases 145 per 100,000 population on the day of specimen collection to observed values of SARS-CoV-2

146 RNA copies per ng of total RNA in primary sludge. The model structure is

$$
\text { case rate }_{i, t}=\alpha_{0}+\alpha_{i}+\sum_{j=0}^{\tau}\left(\beta_{j}+\beta_{i, j}\right) R N A_{i, t-j}+\sum_{d=2}^{7}\left(\gamma_{d}+\gamma_{i, d}\right) 1\left\{w_{t}=d\right\}+\epsilon_{i t}
$$

149 (eq. 1)

150 where the reported case rate is the number of new cases reported by date of specimen collection

151 per 100,000 population, $i$ represents municipality, $t$ represents time (days), $\alpha_{0}$ is the model

152 offset, $\alpha_{i}$ is the individual municipality model offset, $j$ is the number of lagged days, $\tau$ is the

153 maximum number of lagged days, $R N A_{i, t-j}$ are RNA concentrations (SARS CoV-2 RNA copies

$\left.154 \mathrm{ng}^{-1} \mathrm{RNA}\right), w_{t}$ indicates the day of the week on day $t, \beta_{j}, \beta_{i, j}$ and $\gamma_{d}$ and $\gamma_{i, d}$ are regression

155 coefficients, $d$ is day of the week (Friday is the reference day), and $\epsilon_{i t}$ is the residual error

156 associated with each observation. Day of the week addresses the known daily variations in

157 testing behavior. ${ }^{16}$ Adjustment for population, which shows a strong collinearity with average

158 treatment plant flow (simple linear regression: slope $=0.9 \mathrm{~m}^{3} \mathrm{~d}^{-1}$ person ${ }^{-1}, \mathrm{R}^{2}=0.93, \mathrm{p}=0.002$ ), 
medRxiv preprint doi: https://doi.org/10.1101/2021.04.27.21256140; this version posted April 27, 2021. The copyright holder for this preprint (which was not certified by peer review) is the author/funder, who has granted medRxiv a license to display the preprint in perpetuity.

It is made available under a CC-BY-ND 4.0 International license .

was accomplished by considering the case rate per 100,000 residents as the dependent variable.

160 A weighted least squares approach was used to weight (by reciprocal of the variance) case rate

161 contributions to the model and reduce heteroskedasticity. A single model covering all treatment

162 facilities was fit using the entire RNA concentration and case rate data set from all six treatment

163 facilities from August 3, 2020 to February 10, 2021.

164 The statistical significance for predictive parameters was analyzed through a two-tailed t-test 165 performed on the regression coefficients for all RNA concentration lags, and treatment plant and 166 day of the week offsets. Akaike Information Criteria (AIC), Bayesian Information Criteria (BIC)

167 F test, and coverage probability (calculated as the proportion of times that measured case rates

168 fell within the $95 \%$ prediction interval of the model-estimated case rates), were used to select the 169 maximum number of lagged RNA concentrations included in the model. A leave-one-out cross 170 validation was utilized to test the model's ability to estimate COVID-19 reported case rates for

171 other wastewater catchments. Six regression models, similar to Equation 1, with the exception 172 that municipality was not included, were trained by leaving out data from one of the six

173 treatment facilities. These models were then utilized to estimate case rates in the cities covered 174 by the treatment facility excluded from the model training set.

176 Results

177 SARS-CoV-2 concentrations. The SARS-CoV-2 RNA concentrations in primary sludge for

178 the six treatment facilities are shown in Figure 1 from August 3, 2020 to February 10, 2021 and 179 reflect fall COVID-19 outbreaks in each city. The bottom row of Figure 1 displays the reported 180 case rates over the same time period in the municipalities served by the six treatment plants. The 181 timing of SARS-CoV-2 RNA concentrations in primary sludge visually tracks the dynamics in 
medRxiv preprint doi: https://doi.org/10.1101/2021.04.27.21256140; this version posted April 27, 2021. The copyright holder for this preprint (which was not certified by peer review) is the author/funder, who has granted medRxiv a license to display the preprint in perpetuity.

It is made available under a CC-BY-ND 4.0 International license.

182 reported case rates, with observed increases in primary sludge RNA concentrations at each plant 183 coinciding with the start of the fall 2020 outbreaks for the corresponding cities.

184 Model selection and validation. This study estimated COVID-19 case rates using the

185 regression model presented in equation 1 which included lagged SARS-CoV-2 RNA wastewater 186 concentrations, municipality, and day of the week as variables. An initial analysis was conducted

187 to determine the maximum number of prior days of wastewater RNA concentrations $\left(R N A_{i, t-j}\right.$,

188 lagged days) to use. Table 2 presents Akaike Information Criterion (AIC), Bayesian Information

189 Criterion (BIC), F statistics with $\mathrm{p}$ values, and coverage probabilities for maximum lags ranging

190 from 0 to 6 days and indicates optimal model fit with minimized model complexity when using

191 lagged RNA concentrations from 0 to 4 days. Graphical comparisons of measured reported case

192 rates versus model-estimated case rates are provided in Figure 2 for each WWTP using models

193 with lagged RNA concentrations from 0 to 4 days. When applied to the six individual

194 municipalities, resulting coverage probabilities range was 0.93 to 0.96 , with a root mean standard

195 error of 13.1 cases per 100,000 population for the entire model (see Figure $\mathbf{S} 1$ for model

196 confidence intervals). Tables S1-7 provide regression coefficients, intercepts, and their

197 significance for the general linear models in Equation 1. Regression coefficients were typically

198 greatest at lags 0 and 1 day.

199 Results of the leave-one-out cross validation analysis revealed coverage probabilities (95\%

200 prediction intervals) of the estimated case rates that ranged from 0.90 to 0.98 for the six different

201 municipalities considered, suggesting that the model can provide estimates of measured cases

202 from sludge SARS-CoV-2 RNA concentrations for a variety of wastewater catchments that

203 contain treatment facilities that produce primary sludge (Table 3).

204 
medRxiv preprint doi: https://doi.org/10.1101/2021.04.27.21256140; this version posted April 27, 2021. The copyright holder for this preprint (which was not certified by peer review) is the author/funder, who has granted medRxiv a license to display the preprint in perpetuity.

It is made available under a CC-BY-ND 4.0 International license .

\section{Discussion}

206 Estimating the number of infections directly from wastewater pathogen concentrations is a

207 central goal of wastewater surveillance practice. The gut tropism of coronaviruses and

208 widespread COVID-19 testing provide a unique opportunity to develop these tools. We

209 monitored daily SARS-CoV-2 RNA concentrations in the primary sludge of six wastewater

210 treatment plants that covered 18 U.S. municipalities and explored regression analyses to estimate

211 COVID-19 cases rates on the day of specimen collection. Our results demonstrate the feasibility,

212 utility, and simplicity of estimating COVID-19 case rates across a variety of different wastewater

213 treatment catchments.

214 Prior studies have noted a concordance in wastewater SARS-CoV-2 RNA concentrations with

215 other indicators of infection. Early work in the 2020 COVID-19 outbreak observed similar

216 behavior between reported daily positive COVID-19 testing results in a community and the

217 SARS-CoV-2 RNA concentrations in that community's wastewater, ${ }^{17}$ and relationships between

218 wastewater RNA concentrations and COVID-19 reported cases have been reported for SARS-

219 CoV-2 and polio virus. ${ }^{2,7,18,19}$ Several features of this study are unique to these prior studies

220 and mark advances in the science underpinning wastewater-based epidemiology. We estimate

221 COVID-19 case rates solely from current and prior days of primary sludge RNA concentrations

222 and day of the week across treatment plants that range in more than one order of magnitude in

223 size as measured by average flow rate and population served. Inclusion of concentration data

224 from prior days yielded a model that can accounts for the previously observed offsets ${ }^{6,7,18}$

225 between wastewater RNA concentrations and reported case data. The regression model used

226 revealed that concentration lags of 0 to 1 day best predict case rates and confirms the previously

227 described 0 to 2 day lag between case rates by date of specimen collection and SARS-CoV-2 
medRxiv preprint doi: https://doi.org/10.1101/2021.04.27.21256140; this version posted April 27, 2021. The copyright holder for this preprint (which was not certified by peer review) is the author/funder, who has granted medRxiv a license to display the preprint in perpetuity.

It is made available under a CC-BY-ND 4.0 International license.

concentrations in primary sludge ${ }^{6}$. A single general regression model trained by pooled plant data in a leave-one-out analysis was able to accurately estimate case rates for communities served by different domestic treatment plants, suggesting that this model could be extended more broadly to a variety of communities. In this case, treatment plants produced sludge using different primary treatment schemes and served populations that varied by more than an order of magnitude in size (Table 1). The approach for utilizing primary sludge instead of raw wastewater allows for rapid sampling of a mixed influent stream without the use of specialized sampling equipment. The concentration of SARS-CoV-2 in wastewater solids is greater than that in raw wastewater ${ }^{3}$ and negates the need for concentration steps often required when using untreated wastewater. The $0.5 \mathrm{ml}$ sample volume considered in this study should enable automation of RNA extraction. SARS-CoV-2 concentrations are likely not impacted by precipitation events (infiltration and inflow) that might dilute concentrations of SARS-CoV-2 in the aqueous phase of raw wastewater.

The ability to estimate case rates from etiological agent concentrations in wastewater can be of significant epidemiological value. Case rates are a commonly used as a proxy for changes in community infection, and have been used as the standard for implementing non-pharmaceutical interventions and policies to reduce COVID-19 transmission and associated hospitalizations and deaths. In jurisdictions where testing is limited or does not exist, these models can be used as an independent estimate of infection rates. Wastewater RNA concentrations can be reported the same day the sample is collected, thus the statistical models used herein can be utilized to estimate up-to-date reported case rates in a community when COVID-19 testing data lags.

Limitations. This modeling approach relies on statistical relationships between wastewater primary sludge RNA concentrations and COVID-19 case rates, which are primarily based on 
medRxiv preprint doi: https://doi.org/10.1101/2021.04.27.21256140; this version posted April 27, 2021. The copyright holder for this preprint (which was not certified by peer review) is the author/funder, who has granted medRxiv a license to display the preprint in perpetuity.

It is made available under a CC-BY-ND 4.0 International license.

251 diagnostic test results. The reported prediction intervals reflect the variability in these reported

252 case rates. While commonly used as a proxy, reported cases are believed to underestimate

253 infection due to asymptomatic COVID-19 infections. ${ }^{20}$ Clinical testing volumes in the

254 municipalities considered were dynamic over the study period; responding to events such as

255 school openings, holidays, and shifting of resources to locations with increasing case rates. The

256 measured RNA concentrations in wastewater are not subject to such variation in testing policy

257 and should therefore exhibit a more direct relationship to the unobservable changes in SARS-

258 CoV-2 infection in the community. While clinical testing data is considered an imperfect

259 measure of infection, even in locations with strong testing programs, we note that the data

260 resulting from testing programs has been indispensable in understanding the progression of

261 outbreaks and initiating action to stem the spread of COVID-19 throughout the world. That case

262 results can be estimated from SARS-CoV-2 concentrations in sewage sludge provides an added

263 measure of confidence in the use of reported cases to monitor the epidemic.

264 Summary. Measuring the concentration of pathogens in domestic wastewater can be a useful

265 indicator of infection trends within a population. This study demonstrated that a single regression

266 model populated by daily lagged SARS-CoV-2 sewage sludge concentrations could estimate

267 COVID-19 case rates across communities served by six different wastewater treatment facilities.

268 Cross-validation by leave-out analysis suggests the regression model can provide estimates of

269 COVID-19 case rates for a broad variety of treatment facilities that produce primary sludge.

270 Estimating case rates from wastewater pathogen concentrations can be useful in locations with

271 limited or delayed COVID-19 testing programs or for infectious diseases where individual

272 testing programs are not well-developed.

273 
medRxiv preprint doi: https://doi.org/10.1101/2021.04.27.21256140; this version posted April 27, 2021. The copyright holder for this preprint (which was not certified by peer review) is the author/funder, who has granted medRxiv a license to display the preprint in perpetuity.

It is made available under a CC-BY-ND 4.0 International license.

\section{Acknowledgements}

277 This project was supported by Cooperative Agreement no. 6NU50CK000524-01 from the

278 Centers for Disease Control and Prevention using funds from the COVID-19 Paycheck

279 Protection Program and Health Care Enhancement Act Response Activities. This activity was

280 reviewed by CDC and was conducted consistent with applicable federal law and CDC policy.

281 See e.g., 45 C.F.R. part 46.102(1)(2), 21 C.F.R. part 56; 42 U.S.C. 241(d); 5 U.S.C. $552 a ; 44$

282 U.S.C. 3501 et seq. The findings and conclusions of this report are those of the author(s) and do

283 not necessarily represent the official position of the Centers for Disease Control and Prevention.

284 We wish to thank the Stamford, Bridgeport West, New Haven, Hartford South Meadows,

285 New London, and Norwich, CT wastewater treatment facilities for assistance in sampling and

286 participation in the study.

287

\section{Supporting Information}

289 General offset and coefficients for the regression model (Table S1), Stamford specific offset and 290 coefficients for the regression model (Table S2), New Haven specific offset and coefficients for

291 the regression model (Table S3), Hartford specific offset and coefficients for the regression

292 model (Table S4), New London specific offset and coefficients for the regression model (Table

293 S5), Norwich specific offset and coefficients for the regression model (Table S6). 


\section{References}

1. Xiao, F.; Tang, M.; Zheng, X.; Liu, Y.; Li, X.; Shan, H., Evidence for gastrointestinal infection of SARS-CoV-2. Gastroenterology 2020, 158, 1831-1833.e3.

2. Medema, G.; Heijnen, L.; Elsinga, G.; Italiaander, R.; Brouwer, A., Presence of SARSCoronavirus-2 RNA in sewage and correlation with reported COVID-19 prevalence in the early stage of the epidemic in The Netherlands. Environmental Science \& Technology

3. Graham, K. E.; Loeb, S. K.; Wolfe, M. K.; Catoe, D.; Sinnott-Armstrong, N.; Kim, S.; Yamahara, K. M.; Sassoubre, L. M.; Mendoza Grijalva, L. M.; Roldan-Hernandez, L.; Langenfeld, K.; Wigginton, K. R.; Boehm, A. B., SARS-CoV-2 RNA in Wastewater settled solids is associated with COVID-19 cases in a large urban sewershed. Environmental Science \& Technology 2021, 55, 488-498.

4. Vallejo, J. A.; Rumbo-Feal, S.; Conde-Pérez, K.; López-Oriona, Á.; Tarrío-Saavedra, J.; Reif, R.; Ladra, S.; Rodiño-Janeiro, B. K.; Nasser, M.; Cid, Á.; Veiga, M. C.; Acevedo, A.; Lamora, C.; Bou, G.; Cao, R.; Poza, M., Predicting the number of people infected with SARS-COV-2 in a population using statistical models based on wastewater viral load. medRxiv 2020, 2020.07.02.20144865.

5. Kaplan, E. H.; Wang, D.; Wang, M.; Malik, A. A.; Zulli, A.; Peccia, J., Aligning SARS-CoV-2 indicators via an epidemic model: application to hospital admissions and RNA detection in sewage sludge. Health Care Management Science 2020.

6. Peccia, J.; Zulli, A.; Brackney, D. E.; Grubaugh, N. D.; Kaplan, E. H.; CasanovasMassana, A.; Ko, A. I.; Malik, A. A.; Wang, D.; Wang, M.; Warren, J. L.; Weinberger, D. M.; Arnold, W.; Omer, S. B., Measurement of SARS-CoV-2 RNA in wastewater tracks community infection dynamics. Nature Biotechnology 2020, 38 , 11641167.

7. Nemudryi, A.; Nemudraia, A.; Wiegand, T.; Surya, K.; Buyukyoruk, M.; Cicha, C.; Vanderwood, K. K.; Wilkinson, R.; Wiedenheft, B., Temporal Detection and Phylogenetic Assessment of SARS-CoV-2 in Municipal Wastewater. Cell Reports Medicine 2020, 1, 100098.

8. Souch, J. M.; Cossman, J. S., A Commentary on Rural-Urban Disparities in COVID-19 Testing Rates per 100,000 and Risk Factors. The Journal of Rural Health 2020, 37,188190.

9. Ondoa, P.; Kebede, Y.; Loembe, M. M.; Bhiman, J. N.; Tessema, S. K.; Sow, A.; Sall, A. A.; Nkengasong, J., COVID-19 testing in Africa: lessons learnt. Lancet Microbe 2020, 1, e103-e104.

10. U.S. Centers for Diseas Control and Prevention, CDC 2019-Novel Coronavirus (2019nCoV) Real-Time RT-PCR Diagnostic Panel. 2020.

11. Vogels, C. B. F.; Brito, A. F.; Wyllie, A. L.; Fauver, J. R.; Ott, I. M.; Kalinich, C. C.; Petrone, M. E.; Casanovas-Massana, A.; Catherine Muenker, M.; Moore, A. J.; Klein, 
medRxiv preprint doi: https://doi.org/10.1101/2021.04.27.21256140; this version posted April 27, 2021. The copyright holder for this preprint

(which was not certified by peer review) is the author/funder, who has granted medRxiv a license to display the preprint in perpetuity. It is made available under a CC-BY-ND 4.0 International license .

J.; Lu, P.; Lu-Culligan, A.; Jiang, X.; Kim, D. J.; Kudo, E.; Mao, T.; Moriyama, M.; Oh, J. E.; Park, A.; Silva, J.; Song, E.; Takahashi, T.; Taura, M.; Tokuyama, M.; Venkataraman, A.; Weizman, O.-E.; Wong, P.; Yang, Y.; Cheemarla, N. R.; White, E. B.; Lapidus, S.; Earnest, R.; Geng, B.; Vijayakumar, P.; Odio, C.; Fournier, J.; Bermejo, S.; Farhadian, S.; Dela Cruz, C. S.; Iwasaki, A.; Ko, A. I.; Landry, M. L.; Foxman, E. F.; Grubaugh, N. D., Analytical sensitivity and efficiency comparisons of SARS-CoV-2 RT-qPCR primer-probe sets. Nature Microbiology 2020, 5 , 1299-1305.

12. Crank, K.; Li, X.; North, D.; Ferraro, G. B.; Iaconelli, M.; Mancini, P.; La Rosa, G.; Bibby, K., CrAssphage abundance and correlation with molecular viral markers in Italian wastewater. Water Research 2020, 184, 116161.

13. Stachler, E.; Kelty, C.; Sivaganesan, M.; Li, X.; Bibby, K.; Shanks, O. C., Quantitative CrAssphage PCR assays for human fecal pollution measurement. Environmental Science \& Technology 2017, 51, 9146-9154.

14. Wu, Z.; Greaves, J.; Arp, L.; Stone, D.; Bibby, K., Comparative fate of CrAssphage with culturable and molecular fecal pollution indicators during activated sludge wastewater treatment. Environment International 2020, 136, 105452.

15. Council of State and Territorial, Update to the standardized surveillance case definition and national notification of 2019 novel coronavirus disease (COVID-19) Interim-20-ID02. 2020.

16. Bergman, A.; Sella, Y.; Agre, P.; Casadevall, A., Oscillations in U.S. COVID-19 Incidence and mortality data reflect diagnostic and reporting factors. mSystems $\mathbf{2 0 2 0}, 5$ (4), e00544-20.

17. Wurtzer, S.; Marechal, V.; Mouchel, J.-M.; Maday, Y.; Teyssou, R.; Richard, E.; Almayrac, J. L.; Moulin, L., Evaluation of lockdown impact on SARS-CoV-2 dynamics through viral genome quantification in Paris wastewaters. medRxiv 2020, 2020.04.12.20062679.

18. Wu, F.; Xiao, A.; Zhang, J.; Moniz, K.; Endo, N.; Armas, F.; Bonneau, R.; Brown, M. A.; Bushman, M.; Chai, P. R.; Duvallet, C.; Erickson, T. B.; Foppe, K.; Ghaeli, N.; Gu, X.; Hanage, W. P.; Huang, K. H.; Lee, W. L.; Matus, M.; McElroy, K. A.; Nagler, J.; Rhode, S. F.; Santillana, M.; Tucker, J. A.; Wuertz, S.; Zhao, S.; Thompson, J.; Alm, E. J., SARS-CoV-2 titers in wastewater foreshadow dynamics and clinical presentation of new COVID-19 cases. medRxiv 2020, 2020.06.15.20117747.

19. Berchenko, Y.; Manor, Y.; Freedman, L.; Kaliner, E.; Grotto, I.; Mendelson, E.; Huppert, A., Estimation of polio infection prevalence from environmental surveillance data. Science Translational Medicine 2017, 9, eaaf6786.

20. He, J.; Guo, Y.; Mao, R.; Zhang, J., Proportion of asymptomatic coronavirus disease 2019: A systematic review and meta-analysis. Journal of Medical Virology 2020, 93:820830. 
medRxiv preprint doi: https://doi.org/10.1101/2021.04.27.21256140; this version posted April 27, 2021. The copyright holder for this preprint (which was not certified by peer review) is the author/funder, who has granted medRxiv a license to display the preprint in perpetuity.

It is made available under a CC-BY-ND 4.0 International license .

\section{Tables and Figures}

401

Table 1. Wastewater treatment plant characteristics

\begin{tabular}{|c|c|c|c|c|}
\hline $\begin{array}{l}\text { WWTP } \\
\text { Name }\end{array}$ & $\begin{array}{l}\text { Municipalities } \\
\text { served (total } \\
\text { population) }\end{array}$ & $\begin{array}{l}\text { Average flow } \\
\text { rate }\left(\mathrm{m}^{3} \mathrm{~d}^{-1}\right)\end{array}$ & $\begin{array}{l}\text { Population } \\
\text { served }\end{array}$ & Primary sludge process details \\
\hline Stamford & $\begin{array}{l}\text { Stamford and } \\
\text { Darien, CT } \\
(151,528)\end{array}$ & 91,000 & 140,000 & $\begin{array}{l}\text { Bar screens } \rightarrow \text { primary clarifier } \rightarrow \text { de- } \\
\text { gritting of primary sludge with } \\
\text { hydrocyclones. Sample of } \\
\text { thickened sludge collected after } \\
\text { hydrocyclones. }\end{array}$ \\
\hline $\begin{array}{l}\text { Bridgeport } \\
\text { West }\end{array}$ & $\begin{array}{l}\text { Bridgeport, CT } \\
(144,900)\end{array}$ & 120,000 & 105,000 & $\begin{array}{l}\text { Bar screens } \rightarrow \text { gravity } \\
\text { thickener } \rightarrow \text { primary clarifier. Sample } \\
\text { collected at primary solids effluent } \\
\text { pump. }\end{array}$ \\
\hline $\begin{array}{l}\text { New } \\
\text { Haven }\end{array}$ & $\begin{array}{l}\text { New Haven, } \\
\text { Hamden, East } \\
\text { Haven, } \\
\text { Woodbridge, CT } \\
(228,862)\end{array}$ & 151,000 & 200,000 & $\begin{array}{l}\text { Bar screen } \rightarrow \text { grit chamber } \rightarrow \text { primary } \\
\text { clarifier } \rightarrow \text { gravity thickener. Sample } \\
\text { collected at effluent pump of gravity } \\
\text { thickener. }\end{array}$ \\
\hline $\begin{array}{l}\text { Hartford, } \\
\text { South } \\
\text { Meadows }\end{array}$ & $\begin{array}{l}\text { Hartford, West } \\
\text { Hartford, } \\
\text { Newington, } \\
\text { Bloomfield, } \\
\text { Wethersfield, CT } \\
(263,021) \\
\end{array}$ & 300,000 & 300,000 & $\begin{array}{l}\text { Bar screen } \rightarrow \text { grit chamber } \rightarrow \text { primary } \\
\text { clarifier } \rightarrow \text { gravity thickener. Sample } \\
\text { collected at effluent pump of gravity } \\
\text { thickener. }\end{array}$ \\
\hline $\begin{array}{l}\text { New } \\
\text { London }\end{array}$ & $\begin{array}{l}\text { New London and } \\
\text { Waterford, CT } \\
(45,826)\end{array}$ & 23,000 & 40,000 & $\begin{array}{l}\text { Bar screen grit chamber } \rightarrow \text { primary } \\
\text { sedimentation. Sample collected at } \\
\text { primary solids pump. }\end{array}$ \\
\hline Norwich & $\begin{array}{l}\text { Norwich, } \\
\text { Sprague, } \\
\text { Franklin, Bozrah } \\
(46,495)\end{array}$ & 32,000 & 22,500 & $\begin{array}{l}\text { Bar screen } \rightarrow \text { grit chamber } \rightarrow \text { primary } \\
\text { clarifier } \rightarrow \text { gravity thickener. Sample } \\
\text { collected at effluent pump from } \\
\text { gravity thickener. }\end{array}$ \\
\hline
\end{tabular}


medRxiv preprint doi: https://doi.org/10.1101/2021.04.27.21256140; this version posted April 27, 2021. The copyright holder for this preprint (which was not certified by peer review) is the author/funder, who has granted medRxiv a license to display the preprint in perpetuity.

It is made available under a CC-BY-ND 4.0 International license .

Table 2. Resulting parameters for model selection to determine the maximum lagged RNA concentration.

\begin{tabular}{|c|c|c|c|c|}
\hline $\begin{array}{c}\text { Maximum } \\
\text { lag } \tau\end{array}$ & AIC & BIC & F statistic (p value) & $\begin{array}{c}\text { Coverage } \\
\text { Probability }\end{array}$ \\
\hline 0 & 9835 & 10180 & & 0.94 \\
\hline 1 & 9663 & 10048 & $35.6(<0.01)$ & 0.95 \\
\hline 2 & 9613 & 10020 & $12.8(<0.01)$ & 0.95 \\
\hline 3 & 9557 & 10013 & $8.5(<0.01)$ & 0.95 \\
\hline 4 & 9543 & 9999 & $9.2(<0.01)$ & 0.95 \\
\hline 5 & 9521 & 10018 & $3.6(<0.01)$ & 0.95 \\
\hline 6 & 9536 & 10034 & $4.1(<0.01)$ & 0.95 \\
\hline
\end{tabular}

Table 3. Leave-one-out cross validation results

425 for the general model ${ }^{1}$

\begin{tabular}{|c|l|l|}
\hline Town Omitted & $\begin{array}{l}\text { F-statistic }(\mathbf{p} \\
\text { value })\end{array}$ & $\begin{array}{l}\text { Coverage } \\
\text { Probability }\end{array}$ \\
\hline Stamford & $285.6(p<0.001)$ & 0.98 \\
\hline Bridgeport West & $273.4(p<0.001)$ & 0.96 \\
\hline New Haven & $339(p<0.001)$ & 0.91 \\
\hline Hartford & $303.3(p<0.001)$ & 0.91 \\
\hline New London & $315.6(p<0.001)$ & 0.90 \\
\hline Norwich & $291.5(p<0.001)$ & 0.94 \\
\hline
\end{tabular}

426 
medRxiv preprint doi: https://doi.org/10.1101/2021.04.27.21256140; this version posted April 27, 2021. The copyright holder for this preprint (which was not certified by peer review) is the author/funder, who has granted medRxiv a license to display the preprint in perpetuity.

It is made available under a CC-BY-ND 4.0 International license .

Figure 1. (top) Daily SARS-CoV-2 RNA concentrations in primary sludge of the six WWTP's considered in this study. (bottom) Daily COVID-19 cases by date of specimen
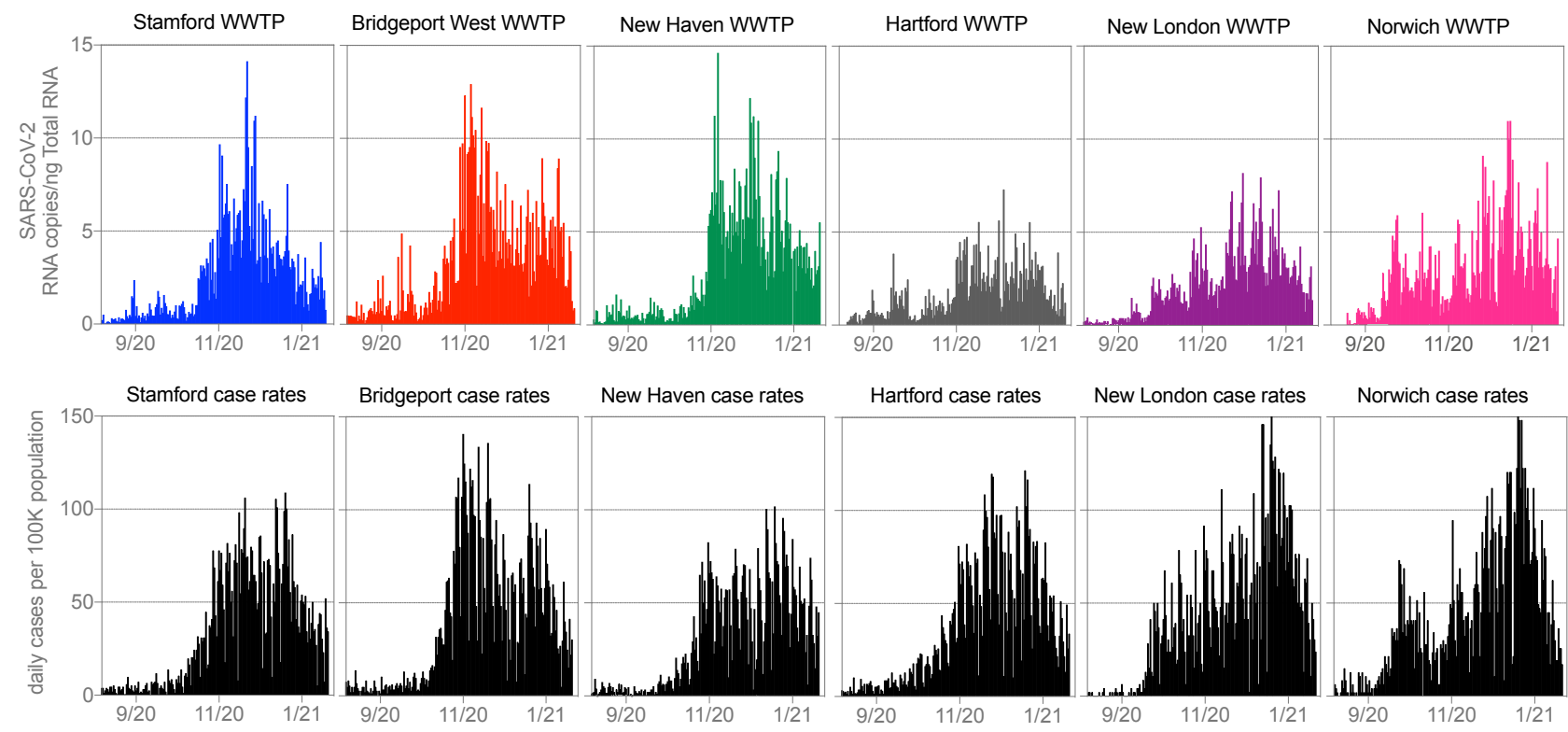

Norwich case rates collection per 100,000 residents for the cities and towns served by the above wastewater treatment plants (see Table 1). 
medRxiv preprint doi: https://doi.org/10.1101/2021.04.27.21256140; this version posted April 27, 2021. The copyright holder for this preprint (which was not certified by peer review) is the author/funder, who has granted medRxiv a license to display the preprint in perpetuity. It is made available under a CC-BY-ND 4.0 International license .

486

487

488

489

490

491

492

493

494

495

496

497

498

499

500

501

502

503

504

505

506

507

508

509

510

511

512

513

514

515

516

517

518

519

520

521

522

523

524

525

526

527

528

529
Stamford Model

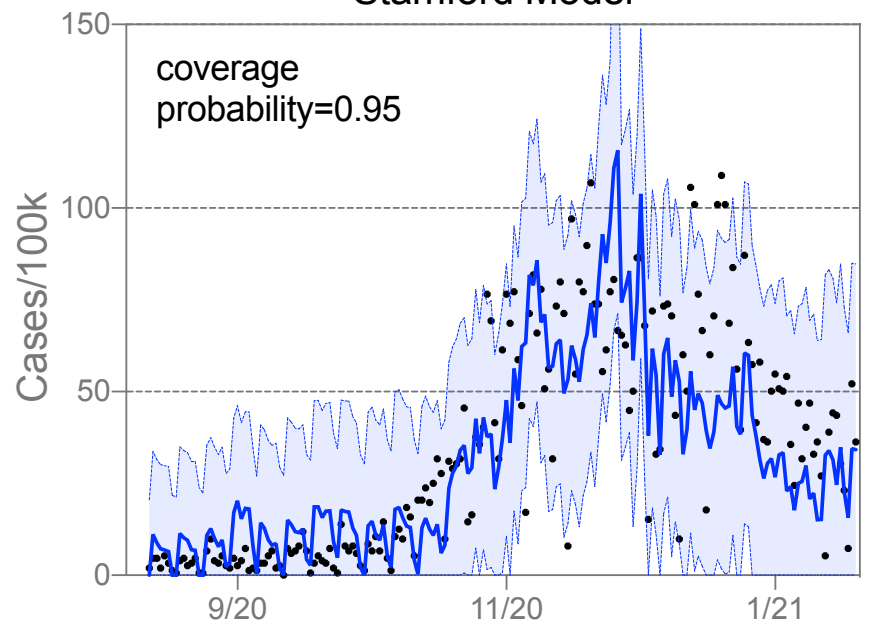

New Haven Model
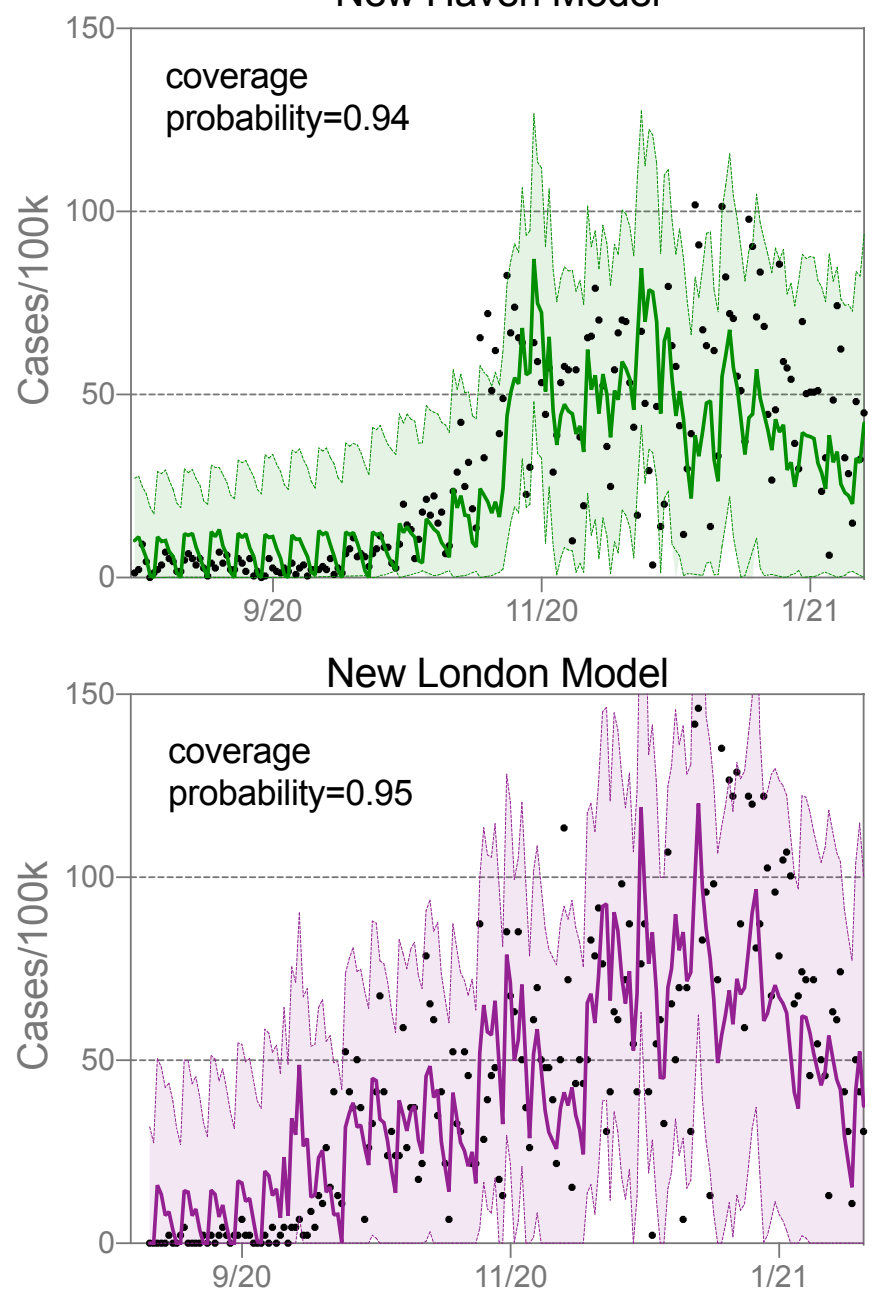

Bridgeport W. Model

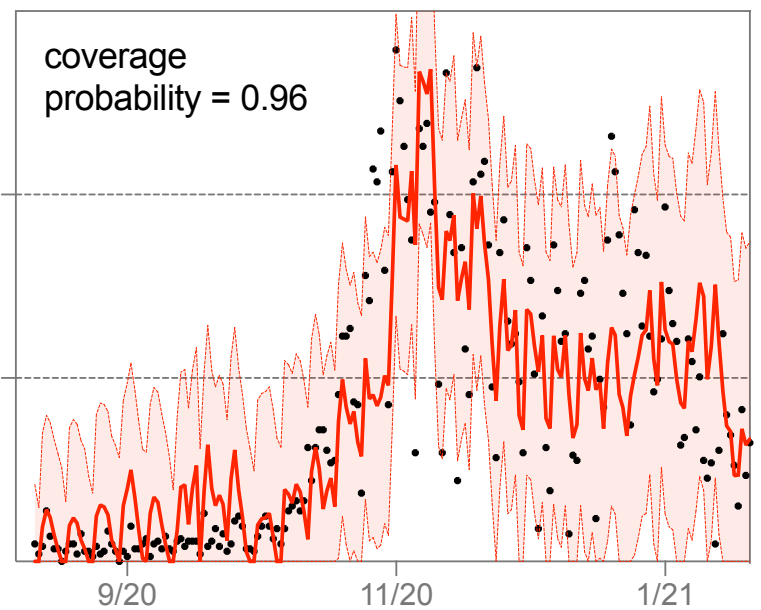

Hartford Model

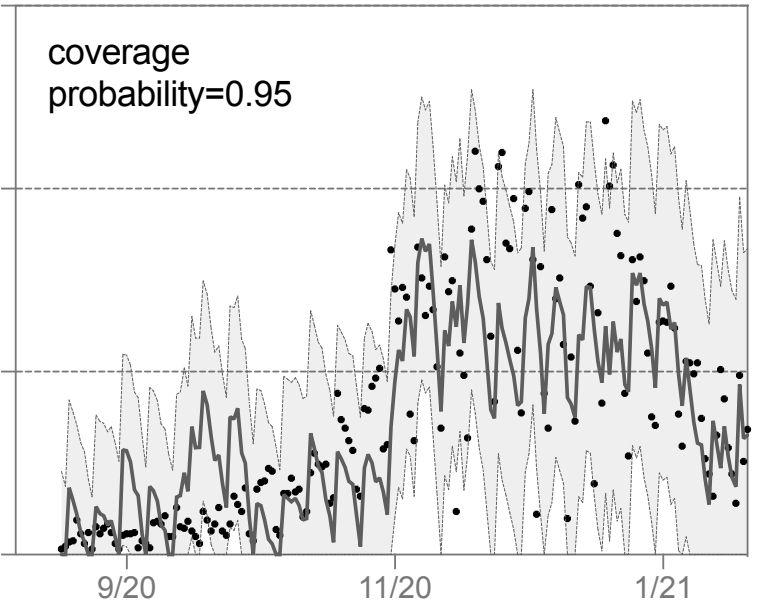

Norwich Model

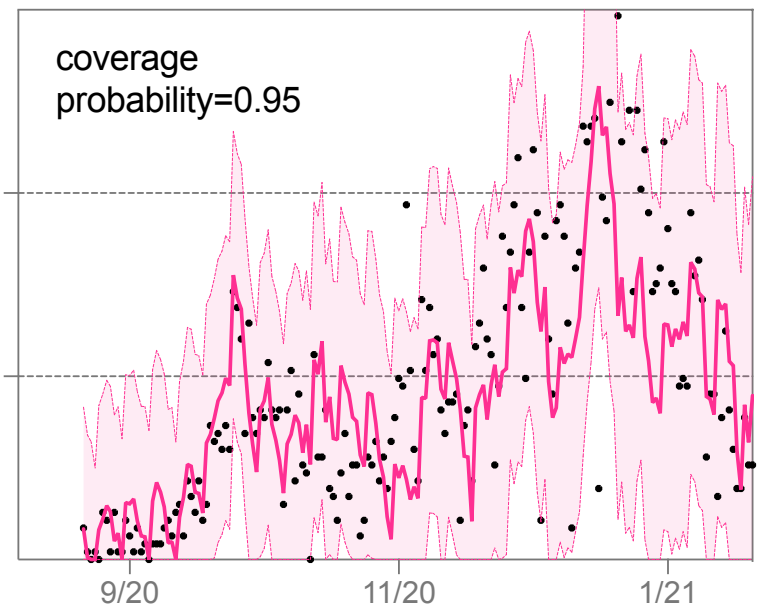

Figure 2. Comparison between COVID-19 case rates by day of clinical specimen collection and estimated case rates using RNA concentrations lagged from 0 to 4 days. The model is depicted by a solid line, measured cases are black dots, and $95 \%$ prediction intervals are shown by shading. $F=37.42, p<0.001$. 